\title{
CHANGES IN THE LEVEL OF CALCIUM, ZINC AND COPPER IN THE SERUM OF HORSES IN RELATION TO THE FEEDING SEASON
}

\section{ZMIANA STEZŻENIA WAPNIA, CYNKU I MIEDZI W SUROWICY KONI W ZALEŻNOŚCI OD SEZONU ŻYWIENIOWEGO}

\author{
Department of Reproduction and Animal Hygiene, Siedlce University of Natural Sciences \\ and Humanities, Poland \\ ${ }^{1}$ Department of Animal Genetics and Horse Breeding, Siedlce University of Natural Sciences \\ and Humanities, Poland \\ ${ }^{2}$ Veterinary Diagnostic Laboratory LAB-WET, Warszawa, Poland
}

\begin{abstract}
Streszczenie. Prawidłowa koncentracja biopierwiastków warunkuje odpowiedni przebieg procesów biochemicznych, a tym samym wpływa na właściwe funkcjonowanie organizmu. Celem pracy było określenie cech gospodarki mineralnej koni, utrzymywanych w rejonie niedoborów mineralnych, jako podstawy oceny ich żywienia. Do badań wytypowano 10 koni (5 klaczy i 5 wałachów) utrzymywanych w podobnych warunkach. Konie były użytkowane w celach rekreacyjno-sportowych. Badania przeprowadzono w dwóch okresach - po zakończeniu sezonu pastwiskowego (koniec listopada 2015 r.) i na początku sezonu pastwiskowego (koniec maja 2016 r.). Krew została pobrana z żyły jarzmowej do sterylnych probówek z koagulantem. Przeprowadzona ocena stężenia miedzi i cynku w surowicy krwi koni wykazuje duże odchylenia od norm fizjologicznych. Stężenia $\mathrm{Cu}$ i Zn w surowicy kształtują się poniżej dolnych poziomów referencyjnych. Na podstawie przeprowadzonych badań trudno jest jednoznacznie wskazać, który z czynników może wywierać decydujący wpływ na kształtowanie się w ciągu roku zawartości wapnia, cynku i miedzi w surowicy krwi koni. Można przypuszczać, że zawartość analizowanych pierwiastków w surowicy koni uwarunkowana jest zasobnością paszy w wapń, cynk i miedź. W związku z tym wskazane byłoby, zarówno w sezonie letnim, jak i zimowym, uzupełnienie podaży miedzi i cynku w dawce pokarmowej koni. Celowe jest także prowadzenie w analizowanym rejonie kolejnych badań w kierunku określenia zaopatrzenia koni w miedź i cynk.
\end{abstract}

Key words: horse, calcium, zinc, copper, nourishment, disease.

Słowa kluczowe: konie, wapń, cynk, miedź, żywienie, choroby.

\section{INTRODUCTION}

The health and use value of horses are significantly influenced by diet and training. Mineral imbalances play a significant role in health problems in horses (Yashiki et al. 1995; Stanek et al. 2016). Mineral nutrients in feed rations for horses are derived from bulky feed, concentrate feed, and mineral supplements (Wagner et al. 2011; Dominguez-Vara et al. 2017; Wyganowska et al. 2017). Feeds used in horse diets are usually locally produced. The content of minerals

Corresponding author - Adres do korespondencji: Katarzyna Andraszek, Departament of Genetics and Horse Breeding, Siedlce University of Natural Sciences and Humanities, Bolesława Prusa 14, 08-110 Siedlce, Poland, e-mail: katarzyna.andraszek@uph.edu.pl 
in feed depends on their content in the soil, fertilizers, and the species of plant (Sutton et al. 2002). A local deficiency of mineral elements in the soil leads to a reduction in their content in plants and in the body (Fradinho et al. 2006). Concentration of elements in animal organisms may also be determined by antagonistic interactions between elements, species, breed, age, sex, and the environment (Asano et al. 2002). Therefore it is important to learn the response of horses to their living environment. Analysis of the composition of the blood of horses is considered a reliable indicator in detecting mineral deficiencies (Forrer et al. 2001). Furthermore, determination of mineral concentrations in the blood of horses is necessary to prevent metabolic disorders.

The correct concentrations of biological elements allow biochemical processes to proceed normally, and thus enable the proper functioning of the organism (Vitti et al. 2005). Even small changes in their concentration in the body impair the function of vitally important systems such as the nervous and skeletomuscular systems (Rieker et al. 2000; Soetan et al. 2010). Elements essential for the proper function of the horse include the macronutrients calcium, phosphorus and magnesium. Micronutrients, such as copper, zinc and selenium, perform equally important functions (Korpal et al. 2016; Stanek et al. 2016). East-central Poland has good geographical conditions for raising livestock, but deficiencies in the supply of minerals to horses are observed in this region (Wyganowska et al. 2017). The aim of the study was to determine characteristics of the mineral metabolism of horses raised in a region characterized by mineral deficiencies as a basis for evaluating their diet.

\section{MATERIAL AND METHODS}

Ten horses ( 5 mares and 5 geldings), kept in similar conditions, were selected for the study. The horses were used for recreation and sport. All of the horses received three meals a day. The meals consisted of barley and oats and always hay (twice a day in the pasture season and three times a day in the winter season). The horses were let out to paddocks every day. Twice a week during the winter season the animals received mash and had permanent access to water. The study was conducted in two periods: after the pasture season (end of November 2015) and at the beginning of the pasture season (end of May 2016). Blood was collected from the jugular vein into sterile test tubes with no coagulant. The animals were in good health at the time of blood collection. Calcium content in the blood serum was determined by the colorimetric method using a BS-800 Chemistry Analyzer (Mindray). Zinc and copper content in the blood serum was determined by the colorimetric method using an A-25 Chemistry Analyzer (BioSystems).

Statistical differences between the samples were determined using Tukey's test and ANOVA (STATISTICA version 10.0, StatSoft Inc., PL). The level of significance was set at $P \leq 0.05$.

\section{RESULTS}

In accordance with the planned timetable, analyses of calcium, copper and zinc content in the blood of the ten horses were performed after the end of the pasture season (in November) and before the start of the pasture season (end of May). Table 1 present the results of the analyses of calcium, zinc and copper content in relation to the feeding season. 
Table 1. Calcium, Zinc and Copper content in the blood of the horses depending on the feeding season

Tabela 1. Zawartość wapnia, cynku i miedzi we krwi koni w zależności od sezonu pastwiskowego

\begin{tabular}{|c|c|c|c|c|c|c|}
\hline \multirow[b]{2}{*}{$\begin{array}{l}\text { Horse } \\
\text { Koń }\end{array}$} & \multicolumn{3}{|c|}{$\begin{array}{c}\text { End of November (after pasture season) } \\
\text { Koniec listopada (po sezonie pastwiskowym) }\end{array}$} & \multicolumn{3}{|c|}{$\begin{array}{c}\text { End of May (before pasture season) } \\
\text { Koniec maja (przed sezonem pastwiskowym) }\end{array}$} \\
\hline & $\begin{array}{c}\text { calcium level/ } \\
\text { stężenie wapnia* } \\
\text { [mmol/l] }\end{array}$ & $\begin{array}{c}\text { zinc level/ } \\
\text { stężenie cynku** } \\
{[\mu \mathrm{mol} / \mathrm{l}]}\end{array}$ & $\begin{array}{c}\text { copper level/ } \\
\text { stężenie miedzi } \\
{[\mu \mathrm{mol} / /]}\end{array}$ & $\begin{array}{l}\text { calcium level/ } \\
\text { stężenie wapnia* } \\
\text { [mmol/l] }\end{array}$ & $\begin{array}{c}\text { zinc level/ } \\
\text { stężenie cynku** } \\
{[\mu \mathrm{mol} / \mathrm{l}]}\end{array}$ & $\begin{array}{c}\text { copper level/ } \\
\text { stężenie miedzi*** }^{* *}[\mu \mathrm{mol} / l]\end{array}$ \\
\hline Mare - Klacz 1 & 3.35 & $7.49 \downarrow$ & $10.06 \downarrow$ & 3.15 & $9.02 \downarrow$ & $10.03 \downarrow$ \\
\hline Mare - Klacz 2 & 3.22 & $9.29 \downarrow$ & $8.78 \downarrow$ & 3.07 & $5.20 \downarrow$ & $10.05 \downarrow$ \\
\hline Mare - Klacz 3 & 3.27 & $5.20 \downarrow$ & $7.99 \downarrow$ & 3.07 & $10.40 \downarrow$ & $16.80 \downarrow$ \\
\hline Mare - Klacz 4 & 3.27 & $7.69 \downarrow$ & $7.58 \downarrow$ & 3.07 & $9.17 \downarrow$ & $9.11 \downarrow$ \\
\hline Mare - Klacz 5 & 3.12 & $8.50 \downarrow$ & $6.59 \downarrow$ & 2.95 & $4.28 \downarrow$ & $11.15 \downarrow$ \\
\hline $\begin{array}{l}\text { Mares - average } \\
\text { Klacze - średnia }\end{array}$ & 3.25 & $7.63 \downarrow$ & $8.20 \downarrow$ & 3.06 & $7.61 \downarrow$ & $11.43 \downarrow$ \\
\hline Gelding - Wałach 1 & 3.22 & $5.18 \downarrow$ & $10.08 \downarrow$ & 3.00 & $28.90 \uparrow$ & $39.40 \uparrow$ \\
\hline Gelding - Wałach 2 & 3.15 & $7.00 \downarrow$ & $10.17 \downarrow$ & 3.07 & $3.98 \downarrow$ & $40.19 \uparrow$ \\
\hline Gelding - Wałach 3 & 3.25 & $5.90 \downarrow$ & $10.99 \downarrow$ & 2.85 & $7.95 \downarrow$ & 20.09 \\
\hline Gelding - Wałach 4 & 3.12 & $6.70 \downarrow$ & $13.56 \downarrow$ & 3.20 & 13.45 & $16.17 \downarrow$ \\
\hline Gelding - Wałach 5 & 3.32 & $7.29 \downarrow$ & $11.18 \downarrow$ & 3.00 & $7.80 \downarrow$ & $9.73 \downarrow$ \\
\hline $\begin{array}{l}\text { Geldings - averange } \\
\text { Wałachy - średnia }\end{array}$ & 3.21 & $6.41 \downarrow$ & $11.20 \downarrow$ & 3.02 & 12.42 & $25.12 \uparrow$ \\
\hline $\begin{array}{l}\text { Horses - averange } \\
\text { Konie - średnia }\end{array}$ & 3.23 & $7.02 \downarrow$ & $9.70 \downarrow$ & 3.04 & $10.02 \downarrow$ & $18.27 \downarrow$ \\
\hline
\end{tabular}

${ }^{*}$ Calcium - reference value - Wapń - wartość referencyjna - 2.68-3.35 [mmol/l].

${ }^{* *}$ Zinc - reference value - Cynk - wartość referencyjna - 11.0-15.0 [ [ $\left.\mathrm{mol} / \mathrm{l}\right]$.

${ }^{* * *}$ Copper - reference value - Miedź - wartość referencyjna - 19.0-21.0 [ $\left.\mu \mathrm{mol} / \mathrm{l}\right]$. 
The serum concentrations of calcium presented in Table 1 are within the range of physiological values and can be considered correct.

Pronounced copper deficiencies were observed in most of the horses (Table 1). Before the pasture season seven of the ten horses had a copper level below the reference value. These included all of the mares tested and two of the five geldings.

After the pasture season, copper deficiency was noted in all of the mares and geldings (Table 1). The mares had a very low level of copper in the blood. The values were below the norms established for horses (19-21 $\mu \mathrm{mol} / \mathrm{l})$, ranging from $6.59 \mu \mathrm{mol} / \mathrm{l}$ to $10.06 \mu \mathrm{mol} / \mathrm{l}$.

Table 2 presents data on the effect of the season of the year on the content of elements in blood collected from mares and geldings. The data indicate that the season influences the level of elements in the blood of horses. The most pronounced effect of the season was noted in the case of $\mathrm{Ca}$. The concentration of this element in the blood differed significantly between the end of November (after the pasture season) and the end of May (before the pasture season) in both mares and geldings ( $\mathrm{P} \leq 0.05)$. In the case of $\mathrm{Zn}$ and $\mathrm{Cu}$, a significant difference was observed only in May in the blood of geldings as compared to the other groups. However, the high standard deviations noted in this group may indicate elevated concentrations of these elements in a single individual, increasing the mean. The level of $Z n$ in the blood collected from geldings in the spring was nearly twice as high as in the remaining groups ( $P \leq 0.05)$, while the concentration of $\mathrm{Cu}$ was twice as high, and in comparison with the blood collected from mares in November, over three times as high ( $\mathrm{P} \leq 0.05)$.

Table 2. The effect of the season of the year on the content of elements in blood collected from mares and geldings

Tabela 2. Wpływ sezonu na zawartość pierwiastków we krwi pobieranej od klaczy i wałachów

\begin{tabular}{|c|c|c|c|c|}
\hline $\begin{array}{l}\text { Sex } \\
\text { Płeć }\end{array}$ & $\begin{array}{l}\text { Season } \\
\text { Sezon }\end{array}$ & $\begin{array}{l}\text { Calcium } \\
\text { Wapń } \\
\bar{x} \pm \text { SD }\end{array}$ & $\begin{array}{l}\text { Zinc } \\
\text { Cynk } \\
\bar{x} \pm \text { SD }\end{array}$ & $\begin{array}{l}\text { Copper } \\
\text { Miedź } \\
\bar{x} \pm S D\end{array}$ \\
\hline \multirow{2}{*}{$\begin{array}{l}\text { Mares } \\
\text { Klacze }\end{array}$} & $\begin{array}{l}\text { end of May (before pasture season) } \\
\text { koniec maja (przed sezonem } \\
\text { pastwiskowym) }\end{array}$ & $3.06^{a} \pm 0.07$ & $7.61^{\mathrm{a}} \pm 2.70$ & $11.43^{\mathrm{a}} \pm 3.09$ \\
\hline & $\begin{array}{l}\text { end of November (after pasture season) } \\
\text { koniec listopada (po sezonie } \\
\text { pastwiskowym) }\end{array}$ & $3.19^{b} \pm 0.09$ & $7.63^{\mathrm{a}} \pm 1.54$ & $8.20^{\mathrm{a}} \pm 1.31$ \\
\hline \multirow{2}{*}{$\begin{array}{l}\text { Geldings } \\
\text { Wałachy }\end{array}$} & $\begin{array}{l}\text { end of May (before pasture season) } \\
\text { koniec maja (przed sezonem } \\
\text { pastwiskowym) }\end{array}$ & $3.02^{\mathrm{a}} \pm 0.13$ & $12.42^{\mathrm{b}} \pm 9.81$ & $25.12^{b} \pm 13.90$ \\
\hline & $\begin{array}{l}\text { end of November (after pasture season) } \\
\text { koniec listopada (po sezonie } \\
\text { pastwiskowym) }\end{array}$ & $3.12^{b} \pm 0.08$ & $6.41^{\mathrm{a}} \pm 0.86$ & $11.20^{\mathrm{a}} \pm 1.41$ \\
\hline Total - Ogółem & & $3.12 \pm 0.12$ & $8.52 \pm 5.30$ & $13.99 \pm 9.42$ \\
\hline
\end{tabular}

$\bar{x}$ - mean value - średnia, SD - standard deviation - odchylenie standardowe.

Mean values in columns marked with different letters differ significantly - Średnie wartości w kolumnach oznaczonych różnymi literami różnią się istotnie: $a, b-P \leq 0.05$.

\section{DISCUSSION}

The issue of mineral deficiencies remains relevant for researchers and for those directly involved in raising animals. Both deficiencies and surpluses of minerals are detrimental to animal health and productivity (Lopez et al. 2000). 
In the present study Ca content ranged from 2.85 to $3.35 \mathrm{mmol} / \mathrm{l}$, and thus in all cases the values obtained were within the normal physiological range (Boyd 1984; Dietz and Huskamp 2006; Winnicka 2015). Similar results were obtained by Lopez et al. (2006), Vervuert et al. (2006), Mohri et al. (2007), Piccione et al. (2008). Lower concentrations of Ca in blood serum were detected by Cymbaluk and Christison (1989). Calcium is one of the most important macronutrients in the horse due to its role in the formation of bones and teeth. Successful reproduction requires complete provisions of calcium (Wong et al. 2001). The effect of enzymes and hormones on organs is dependent on the presence of calcium ions, as is the antigen-antibody reaction-one of the most important immune reactions (Bilal et al. 2004). A calcium deficiency may occur in horses when they are fed mainly on cereal grain. When there is an excess of calcium in the feed, it is not stored in the body but eliminated with the urine (Schryver 1974). Calcium is known to have an antagonistic effect on zinc and copper, involving a decrease in the serum concentration of $\mathrm{Zn}$ and $\mathrm{Cu}$ due to an excessive concentration of calcium (Aubert and Pinta 1977).

Seasonal variation was observed in zinc concentration in the serum of the horses tested. The serum concentration of zinc was in most cases below the lower physiological limit, ranging from 11.0 to $15.0 \mu \mathrm{mol} / \mathrm{l}$. The physiological role of zinc consists in its direct influence on enzymatic processes (Korenekova et al. 2006). Variation in zinc content in the serum may be determined by climatic and dietary changes during the year, the physiological state of the animal and the synergistic or antagonistic interactions of elements (Birick et al. 2005). Grazing in pastures with poor vegetation may lead to zinc deficiencies in horses (Auer et al. 1989). A deficiency of this element may also occur in horses due to impaired zinc absorption from the gastrointestinal tract, which affects the pool of reserves of this element in the body (Schryver et al. 1980). A reduction in zinc concentration is also observed in horses with respiratory disease or piroplasmosis (Murase et al. 2013). Changes in serum concentration of zinc may result from the antagonistic interaction of $\mathrm{Zn}$ and $\mathrm{Ca}$ during absorption from the gastrointestinal tract, which impairs utilization of $Z n$ in horses (Danek et al. 1995). Copper and cadmium also interact with zinc. When the content of copper and cadmium in feed is high, a relative deficiency of zinc may occur. A zinc deficiency can impair immune function and has a detrimental effect on reproduction (Wong et al. 2001, De Simone et al. 2013).

The normal level of copper in the blood serum of horses ranges from 19.0 to $21.0 \mu \mathrm{mol} / \mathrm{l}$ (Kuleta 1993; Dietz and Huskamp 2006), and thus the results shown in Table 4 are in most cases below the norm. The horses selected for observation showed no symptoms of copper deficiency. Copper deficiency in horses may lead to disturbances in the growth and development of long bones or to deformation of joints and limbs (Gehrke 1997). The association between copper metabolism and estrogenic hormones is manifested as reproductive disorders during periods of deficiency of this element (Tuormaa 2000; Heidarpour et al. 2008). As an antibody activator copper plays a role in systemic immune processes. It affects the bioavailability of iron and enables its absorption (Rosen et al. 1995; Aytekin et al. 2011). A reduced serum concentration of copper in horses may be observed in the case of excessive concentrations of antagonistic elements, such as calcium (Vranković et al. 2015). 


\section{CONCLUSION}

The evaluation of the concentrations of copper and zinc in the blood serum of the horses revealed substantial deviations from physiological norms. The serum concentrations of $\mathrm{Cu}$ and $\mathrm{Zn}$ were below the lower reference levels. On the basis of the study it is difficult to conclusively state which factor is decisive in determining the content of calcium, zinc and copper in the serum of horses over the course of the year. It seems likely that the serum concentrations of these elements may be determined by their content in the horses' feed. Therefore it would be advisable to supplement the supply of copper and zinc in the feed ration in both the summer and winter seasons. Moreover, further research should be conducted in the region to determine the supply of copper and zinc to horses.

\section{REFERENCES}

Asano R., Suzuki K., Otsuka T., Otsuka M., Sakurai H. 2002. Concentrations of toxic metals and essential minerals in the mane hair of healthy racing horses and their relation to age. J. Vet. Med. Sci. 64, 607-610.

Aubert H., Pinta M. 1977. Trace elements in soil. New York, USA, Elsevier.

Auer D.E., Ng J.C., Thompson H.L., Inglis S., Seawright A.A. 1989. Acute phase response in horses: changes in plasma cation concentrations after localised tissue injury. Vet. Rec. 124, 235-239.

Aytekin I., Onmaz A.C., Aypak S.U., Gunes V., Kucuk O. 2011. Changes in serum mineral concentrations, biochemical and hematological parameters in horses with pica. Biol. Trace Elem. Res. 139, 301-307.

Bilal T., Ercag E., Demirel G., Bilal T. 2004. Comparison of some blood parameters, serum vitamin E and mineral concentrations of Arabian and English Thoroughbred race horses. Vet. Glasnik 58, 135-143.

Birick H., Ocal N., Gucus A.I., Ediz B., Uzman M. 2005. Seasonal changes of some mineral status in mares. J. Equine Vet. Sci. 25, 346-348.

Boyd J.W. 1984. The interpretation of serum biochemistry tests results in domestic animals. Vet. Clin. Pathol. 13, 7-14.

Cymbaluk N.F., Christison G.I. 1989. Effects of dietary energy and phosphorus content on blood chemistry and development of growing horses. J. Anim. Sci. 67, 951-958.

Danek J., Wiśniewski E., Krumrych W., Dąbrowska J. 1995. Wpływ nadmiaru wapnia w paszy na wskaźniki hematologiczne oraz biochemiczne w surowicy krwi i sierści ogierów [The effect of excess calcium in feed on haematological and biochemical parameters of stallion plasma and hair]. Med. Weter. 51, 544-546. [in Polish]

De Simone E.A., Bottini J.M., Alvarez E.A., Barbara A.C. 2013. Association between low serum zinc concentration and hypogammaglobulinemia in foals of different categories. J. Equine Vet. Sci. 33, 401-405.

Dietz O., Huskamp B. 2006. Handbuch Pferdepraxis, 3rd ed. Stuttgard, Enke Verlag.

Dominguez-Vara I., Sanchez-Malvaez E., Medina-Navarro P., De Oca-Jimenez R.M., Alberto R.V., Morales-Almaraz E., De La Fuente J.L., Sanchez-Torres J.E., Borquez-Gastelum J.L., Acosta-Dibarrat J., Salem A.Z.M. 2017. Mineral status and interrelationship in soil, forage, and blood serum of horses in the rainy and dry seasons. J. Equine Vet. Sci. 49, 101-107.

Forrer R., Gautschi K., Lutz H. 2001. Simultaneous measurement of the trace elements Al., As, B, Be, $\mathrm{Cd}, \mathrm{Co}, \mathrm{Cu}, \mathrm{Fe}, \mathrm{Li}, \mathrm{Mn}, \mathrm{Mo}, \mathrm{Ni}, \mathrm{Rb}, \mathrm{Se}, \mathrm{Sr}$, and $\mathrm{Zn}$ in human serum and their reference ranges by ICP-MS. Biol. Trace Elem. Res. 80, 77-93. 
Fradinho M.J., Ferreira-Dias G., Mateus L., Santos-Silva M.F., Agricola R., Barbosa M., Abreu J.M. 2006. The influence of mineral supplementation on skeleton formation and growth in Lusitano foals. Livestock Sci. 104, 173-181.

Gehrke M. 1997. Copper and manganese in the pathogenesis of diseases of the osseous system in animals. Med. Weter. 53, 644-646.

Heidarpour-Bami M., Mohri M., Seifi H.A., Alavi-Tabatabaee A.A. 2008. Effects of parenteral supply of iron and copper on hematology, weight gain, and health in neonatal dairy calves. Vet. Res. Comm. 32, 553-561.

Korenekova B., Skalicka M., Nad P. 2006. Zinc in cattle from area polluted by long-term emissions. Bull. Environ. Contam. Toxicol. 76, 684-688.

Korpal A., Woźniak K., Terman A. 2016: Selenoprotein P gene (SEPP1) as a selenium marker concentration. Folia Pomer. Univ. Technol. Stetin., Agric., Aliment., Pisc., Zootech. 328, 117-122.

Kuleta Z. 1993. Wartości wskaźników hematologicznych i biochemicznych zwierząt w stanach zdrowia i choroby. Olsztyn, ART. [in Polish]

Lopez A.M., Benedito J.L., Miranda M., Castillo C., Hernandez J., Shore R.F. 2000. Arsenic, cadmium, lead, copper and zinc in cattle from Galicia, NW Spain Sci. Total Environ. 246, 237-248.

Lopez I., Mendoza F.J., Mayer-Valor R., Augilera-Tejero E. 2006. Fractination of calcium and magnesium in equine serum. Am. J. Vet. Res. 67, 463-466.

Mohri M., Allahyari L., Sordari K. 2007. Effects of common anticoagulants on routine plasma biochemistry of horse and comparison with serum. J. Equine Vet. Sci. 27, 234-238.

Murase H., Sakai S., Kusano K., Hobo S., Nambo Y. 2013. Serum zinc levels and their relationship with diseases in race horses. J. Vet. Med. Sci. 75, 37-41.

Piccione G., Assenza A., Fazio F., Bergero D., Caola G. 2008. Daily rhythm of serum vitamin D-metabolites, calcium and phosphorus in horses. Acta Vet. Brno 77, 151-157.

Rieker J.M., Cooper S.R., Topliff D.R., Freeman D.W., Teeter R.G. 2000. Copper balance in mature geldings fed supplemental molybdenum. J. Equine Vet. Sci. 20, 522-525.

Rosen A.C., Rosen H.R., Huber K., Bauer K., Ausch C., Redlich K., Klein M.J., Moroz C. 1995. Correlation of placental isoferritin with birth weight and time point of first contractions. Gynecol. Obstet. Invest. 39, 11-14.

Schryver H.F., Hintz H.F., Lowe J.E. 1974. Calcium and phosphorus in the nutrition of the horse. Cornell Vet. 64, 493-514.

Schryver H.F., Hintz H.F., Lowe J.E. 1980. Absorption, excretion and tissue distribution of stable zinc and ${ }^{65}$ zinc in ponies. J. Anim. Sci. 51, 896-902.

Soetan K.O., Olaiya C.O., Oyewole O.E. 2010. The importance of mineral elements for humans, domestic animals and plants: A review. Afr. J. Food Sci. 4, 200-222.

Stanek M., Jaworski Z., Sobotka W., Lipiński K., Olenkowicz R. 2016. Influence of an organic supplement of copper, zinc and manganese in feed rations on concentrations of these elements in the coat of Polish Konik horses. J. Elem. 21, 549-558.

Sutton P., Maskall J., Thornton I. 2002. Concentrations of major and trace elements in soil and grass at Shimba Hills national reserve, Kenya. Appl. Geochem. 17, 1003-1016.

Tuormaa T.E. 2000. Chromium, selenium and copper and other trace minerals in health and reproduction. J. Orthomol. Med. 15, 145-157.

Vervuert I., Stanik K., Coenen M. 2006. Effects of different levels of calcium and phosphorus intake on calcium homeostasis in exercising horses. J. Equine Vet. Sci. 36, 659-663.

Vitti D.M.S.S., Kebreab E., Lopes J.B., Abdalla A.L., France J. 2005. Effects of dietary supplementation on phosphorus metabolism in sheep. J. Anim. Vet. Adv. 4, 349-355.

Vranković L., Aladrović J., Beer-Ljubić B., Zdelar-Tuk M., Stojević Z. 2015. Seasonal changes in enzyme activities and mineral concentrations in Holstein stallions blood plasma. Vet. Archiv. 85, 235-246. 
Wagner E.L., Potter G.D., Gibbs P.G., Eller E.M., Scott B.D., Vogelsang M.M., Walzem R.L. 2011. Copper and zinc balance in exercising horses fed 2 forms of mineral supplements. J. Anim. Sci. 89, 722-728.

Winnicka A. 2015. Wartości referencyjne podstawowych badań laboratoryjnych $w$ weterynarii. Warszawa, Wydaw. SGGW. [in Polish]

Wong W.Y., Flik G., Groenen P.M., Swinkels D.W., Thomas C.M., Copius-Peereboom J.H.J., Merkus H.M.W.M., Steegers-Theunissen R.P.M. 2001. The impact of calcium, magnesium, zinc, and copper in blood and seminal plasma on semen parameters in men. Reprod. Toxicol. 15, 131-136.

Wyganowska A., Jania B., Danielewicz A., Górski K., Andraszek K. 2017. The effect of selenium on proper body function in horses. J. Anim. Plant Sci. (in press).

Yashiki K., Kusunose R., Tagaki S. 1995. Diurnal variations of blood constituents in young Thoroughbred horses. J. Equine Sci. 6, 91-97.

\begin{abstract}
The correct concentrations of biological elements allow biochemical processes to proceed normally, and thus enable the proper functioning of the organism. The aim of the study was to determine characteristics of the mineral metabolism of horses raised in a region characterized by mineral deficiencies as a basis for evaluating their diet. Ten horses were selected for the study ( 5 mares and 5 geldings), all kept in similar conditions. The horses were used for recreation and sport. The study was conducted in two periods: after the pasture season (end of November 2015) and at the beginning of the pasture season (end of May 2016). Blood was collected from the jugular vein into sterile test tubes without coagulant. The evaluation of the concentrations of copper and zinc in the blood serum of the horses revealed substantial deviations from physiological norms. The serum concentrations of $\mathrm{Cu}$ and $\mathrm{Zn}$ were below the lower reference levels. On the basis of the study it is difficult to conclusively state which factor is decisive in determining the content of calcium, zinc and copper in the serum of horses over the course of the year. It seems likely that the serum concentrations of these elements may be determined by their content in the horses' feed. Therefore it would be advisable to supplement the supply of copper and zinc in the feed ration in both the summer and winter seasons. Moreover, further research should be conducted in the region to determine the supply of copper and zinc to horses.
\end{abstract}

